\title{
Conditions of Leaks Formation in Load-bearing Structures of Underground Buildings
}

\author{
Elena Kulikova \\ Construction of Underground Structures and Mining Enterprises \\ National University of Science and Technology "MISiS" \\ Moscow, Russia \\ fragrante@mail.ru
}

\begin{abstract}
Formation of leaks and "fistulas" in concrete lining of underground structures is associated with the local density of concrete, which is characterized by its water resistance. Capes and intermittent streams of groundwater negatively changes the resistance of individual sections of the concrete lining of mine workings. The solution to the problem of ensuring the filtration reliability of underground structures requires a quantitative assessment of the probability of leakages, and, therefore, the determination of the allowable filtration coefficient of the weakest local areas of concrete and reinforced concrete lining of underground structures. The problem of sealing the underground structure should be solved not only by improving the concrete lining. This raises the question of the measures to control the characteristics of the condition of the soil massif.
\end{abstract}

Keywords- leaks, flow, fistulas, coefficient of filtration, underground structure, density, lining, concrete

\section{INTRODUCTION}

Formation of leaks and "fistulas" in concrete lining of underground structures is associated with the local density of concrete, characterized by its water resistance. It is common knowledge [1], [2] that water resistance of concrete depends on more than 14 factors, among which the main is degree and character of porosity of a material, which, in its turn, depends on a water-cement ratio (W/C). It is considered that the larger the pores, the more permeable the concrete. Thus, according to [3], [4], the increase in diameter of the pores in rocks or in concrete by one order of magnitude leads to an increase in the quantity of flowing fluid through them by 10,000 times. According to the Poiseuille's equation, it is the quantity, which during filtration is proportional to the pore radius in the fourth power.

In a complex system of concrete pores [5] this effect is lower, which confirming by the data of Table 1, compiled on the base of [6]. To obtain the table data concrete of 1:2,1:3,12 with cement consumption $350 \mathrm{~kg}$ per $1 \mathrm{~m}^{3}$ of normal-humidity curing were investigated. The volume and size of pores in the samples were determined by the method of mercury porometry.

\section{INFLUENCE OF CONCRETE (W/C) ON ITS WATER RESISTANCE}

The obtained data showed that with an increase of W/C in concrete by 1.75 times its water resistance deteriorates by 2.45 times. At the same time, there is a decrease in fine porosity from 62 to $45 \%$, due to an increase in the average volume (from 27 to $41 \%$ ) and large porosity (from 11 to $14 \%)$.

TABLE I. FILTRATION PARAMETER

\begin{tabular}{|c|c|c|c|}
\hline \multirow{5}{*}{$\begin{array}{l}\text { Average pore } \\
\text { diameter, } \mathrm{mm}\end{array}$} & \multicolumn{3}{|c|}{ Water-cement ratio $\frac{W / C}{\%}$} \\
\hline & $0,4 / 100$ & $\begin{array}{l}0,65 \\
/ 100 \\
\end{array}$ & $\begin{array}{c}0,7 / \\
175 \\
\end{array}$ \\
\hline & \multicolumn{3}{|c|}{$\begin{array}{c}\text { Filtration coefficient } \frac{\mathrm{J}}{\mathrm{m} / \mathrm{s}} \\
\%\end{array}$} \\
\hline & $1,6 / 100$ & $\begin{array}{c}3,14 \\
/ 196 \\
\end{array}$ & $\begin{array}{c}3,9 / \\
245 \\
\end{array}$ \\
\hline & \multicolumn{3}{|c|}{ Pore volume $V \cdot 10^{2}, \frac{\mathrm{m}^{3} / \mathrm{g}}{\%}$} \\
\hline 22,13 & $0,31 / 11$ & $0,53 / 15$ & $0,72 / 14$ \\
\hline 5,13 & $0,77 / 27$ & $1,09 / 32$ & $2,24 / 41$ \\
\hline 1,14 & $1,73 / 62$ & $1,89 / 53$ & $2,47 / 45$ \\
\hline $\begin{array}{l}\text { Total pore volume in } \\
\text { the sample, } v \cdot 10^{2}, \mathrm{~m}^{3} / \mathrm{g}\end{array}$ & $2,81 / 100$ & $3,51 / 125$ & $5,44 / 194$ \\
\hline
\end{tabular}

The change in water resistance of concrete by 2.45 times occurs when the average radius of pores changes from 4.53 $\mathrm{mcm}(\mathrm{W} / \mathrm{C}=0.4)$ to $5.71 \mathrm{mcm}(\mathrm{W} / \mathrm{C}=0.7)$, i.e. by 1.26 times. This confirms the position of the lower effect of changes in the permeability of concrete by variation of the radius of the pores.

The phenomenon of water resistance changes of local concrete sections when W/C changing was studied for concrete of underground structures. Thus, in semi-industrial and industrial experiments have shown that capes and intermittent streams of groundwater negatively changes the resistance of individual sections of the concrete lining of mine workings.

Similar results were founded in the works of [7]. Taking the conclusion about the significant influence of extension (due to capes) moisture on the local water resistance of concrete lining, it's necessary to note that even the lab samples have the location of leakage similar to the above.

During the formation of such looseness, along with small pores of the gel component of the cement stone, pores and channels are formed in the structure of concrete, sometimes 
with a cross-section of 1-2 orders of magnitude superior to the cross-section of the channels of the cement stone [5]. For example, experiments on carefully prepared laboratory samples of high-class concrete (45-60) with a diameter of $300 \mathrm{~mm}$ clearly demonstrated that about $40 \%$ of the samples have concentrated filtration channels (leaks). The same effect is indicated by [2], [5].

\section{A PREMICE FOR LEAKS AND "FISTULAS" FORMATION}

The presence of concentrated channels in concrete, as inherent defects, is a premise for the formation of leaks and "fistulas" in the concrete lining of the underground structure. The quantitative estimation of probability of formation of similar defects of concrete in the considered literary sources is practically not considered.

Concentrated channels develop in the "fistula" under the influence of groundwater filtration and leaching corrosion (corrosion of type I) [3]. The mechanism of this corrosion, revealed in the works of Moskvin, Kinda, etc., is the dissolution of calcium hydroxide $\mathrm{Ca}(\mathrm{OH})_{2}$ by filtered water and washing it out of concrete. Quantity of $\mathrm{Ca}(\mathrm{OH})_{2}$ in Portland cement stone after 1 month of hardening makes 9$11 \%$, after 3 months - reaches $15 \%$ of weight of cement [6]. Leaching $\mathrm{Ca}(\mathrm{OH})_{2}$ by filter water leads to imbalance in the system "hydration products - water" and, ultimately, to the destruction of the cement stone. So, Belit $\left(2 \mathrm{CaO} \cdot \mathrm{Sio}_{2} \cdot \mathrm{aq}\right)$ is stable only in a saturated solution of $\mathrm{Ca}(\mathrm{OH})_{2}$, silicate $\left(3 \mathrm{CaO} \cdot 2 \mathrm{SiO}_{2} \cdot \mathrm{aq}\right)$ - in solutions containing not less than 1.1 $\mathrm{kg}$ of $\mathrm{CaO}$ in one liter and hydroaluminate calcium $\left(3 \mathrm{CaO} \cdot \mathrm{Al}_{2} \mathrm{O}_{3} \cdot 6 \mathrm{H}_{2} \mathrm{O}\right)$ is in equilibrium with a solution containing $1.15 \mathrm{~g} / \mathrm{l}$ of calcium hydroxide. Four-calcium hydroferrite can exist only at the concentration of $\mathrm{CaO}$ in the liquid phase not lower than $1.06 \mathrm{~g} / \mathrm{l}$. At decrease in concentration of $\mathrm{Ca}(\mathrm{OH})_{2}$ in a solution the specified components of a cement stone decompose with loss of binding properties that leads to formation of a through aperture - "fistula".

\section{CORROSION}

Analysis of corrosion conditions of type I allows to reveal the most important of them - admissible coefficient of filtration of water through concrete [7]. Knowing the value of this coefficient and the amount of lime, that can be removed from unit volume of concrete without losing of its basic technical properties $q_{l}, \mathrm{~g} / \mathrm{cm}^{3}$, the amount of water, filtered through a unit volume of concrete in unit time (volume rate of water) $v, \mathrm{~cm}^{3} /\left(\mathrm{cm}^{3} \cdot \mathrm{c}\right)$, the average concentration of lime in the water $c_{l}$, it is possible to determine the duration $\tau$ of design, element or structure:

$$
\begin{aligned}
& \tau=\frac{q_{l}}{V C_{l}}, \\
& q_{l}=K \cdot C \cdot \alpha,
\end{aligned}
$$

where $K$ - the specified allowable percentage of leaching of lime; $C$ - cement content, g per $1 \mathrm{~cm}^{3}$ of concrete or $\mathrm{kg} / \mathrm{l} ; \alpha$ - the $\mathrm{CaO}$ content of the cement, fractions of units.

According to Darcy law

$$
V=K_{f} \cdot \Delta H
$$

where $\Delta H=\frac{H}{\alpha}-$ pressure gradient.

Then the permissible coefficient of concrete filtration can be represented as

$$
K_{f}=\frac{V}{\Delta H},
$$

Substituting formula (1) in (4) we obtain:

$$
\begin{aligned}
& V=\frac{q_{l}}{\tau \cdot C_{l}}, \\
& K_{f}=\frac{q_{l}}{\tau \cdot C_{l} \cdot \Delta H} .
\end{aligned}
$$

The expression (6) obtained by the team of prof. Moskvin allows to determine the required degree of water resistance of both concrete structures of the underground building as a whole and local "spots". The size of $C_{l}$ in the formula (6) is not constant, so it is recommended to determine it experimentally, since a large number of assumptions and the complexity of the corrosion process do not allow sufficiently use of functional dependencies based on the use of general diffusion patterns [3].

The solubility of calcium hydroxide of concrete in water largely depends on the salt content. The $\mathrm{Ca}^{2+}$ and $\mathrm{OH}$ ions, reduce and the ions of $\mathrm{SO}_{4}{ }^{2-}, \mathrm{Cl}^{-}, \mathrm{Na}^{+}, \mathrm{K}^{+}$increase the solubility of calcium hydroxide. Increasing the solubility of $\mathrm{Ca}(\mathrm{OH})_{2}$ and other components of cement stone enhances the development of corrosion type I and accelerates the destruction of concrete.

From the table 2 data of chemical analysis of groundwater in defective areas of the Kalinin radius of the Moscow metro follows that groundwater contains a significant amount of salts that contribute to the rapid dissolution of calcium hydroxide concrete coatings. This, apparently, explains the higher level of leaks of these sites (1 flow per $1 \mathrm{~mm}$ versus 0.06 ) compared with the currents of the Proletarian metro line, where groundwater salinity is much lower.

\section{CONCLUSION}

Summing up the above, it should be noted that the solution to the problem of ensuring the filtration reliability of underground structures requires a quantitative assessment of the probability of leakages, and, therefore, the determination of the allowable filtration coefficient of the weakest local areas of concrete and reinforced concrete lining of underground structures.

This review shows that the problem of sealing the underground structure can not be solved only by improving the concrete lining and raises the question of the measures to control the characteristics of the condition of the soil massif.

Currently, it is possible to control the characteristics of concrete (to increase its density and reduce porosity) by introducing additives (superplasticizers to reduce the watercement ratio) or covering the concrete surface with materials that contribute to the colmatation of pores (Xypex, Calmatron, Penetron, etc.). This helps to increase the water resistance of concrete tunnel lining, its resistance to aggressive influences. However, this is not enough to prevent 
the destruction of concrete when exposed to an aggressive environment.

Protection of concrete lining from corrosion damage can be carried out in two directions: either increasing the density of concrete or protecting concrete with anti-corrosion coatings.

The fight against the filtration and migration of groundwater in the construction is often reduced to improving the waterproofing properties of the lining. However, this method of protection is not always appropriate, economical and the only possible. Moreover, by improving the types of lining is not always possible completely solving the problem of permissible humidity conditions on a particular underground object. Therefore, the most effective solution is to involve the elements of the system "rock mass - underground structure" and control the filtration properties of not only the lining, but, above all, the rock mass.

\section{REFERENCES}

[1] Guide for Design and Construction of Externally Bonded FRP Systems for Strengthening Concrete Structures. ACI 440.2R-08. American Concrete Institute.

[2] CAN/CSA-S806-02 "Design and Construction of Building Components with Fibre-Reinforced Polymers". Canadian Standards Association (CSA). Toronto, Ontario, Canada, 2007, 218p.

[3] Wang, Tao. "Research on the basic strength features of recycled concrete aggregate and recycled concrete". Qingdao: Shandong University Sci. Technol. 2009.

[4] E.M. Zhukov, Y.I. Kropotov, I.A. Loginin, S.I. Polosov, I.A. Legaia.. "Corrosion of reinforced concrete structures and its causes" No.7 The Young scientist. 2016. pp. 78-80.

[5] E.Yu. Kulikova. "Basic Directions of Improving the Durability of the Sewage Collector Lining". in Applied Mechanics and Materials ISBN 978-3-03835-705-6 Design, Construction and Safety of Underground Structures. 2016? p p. 25-32.

[6] E.Yu. Kulikova. "Assessment of ecological compatibility of polymeric materials in underground construction". vol. 20, No. 3, Ecology and industry of Russia, 2016, pp. 28-31.

[7] A.Yu. Fetisov. "Problems of durability of concrete and concrete structures". [Scientific community of students XXI century. Engineering SCIENCE: collection of articles on the Mat. XLIX international. Stud. Scientific.- prakt. Conf. No. 1 (48). URL: https://sibac.info/archive/technic/1(48).pdf]

TABLE II. RESUlTS OF CHEMICAL ANALYSES OF GROUNDWATER

\begin{tabular}{|c|c|c|c|c|c|c|c|c|c|c|c|c|c|c|c|c|c|c|}
\hline \multirow[b]{2}{*}{ 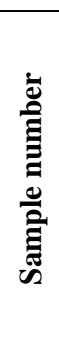 } & \multicolumn{8}{|c|}{ Cations mg/l } & \multirow[b]{2}{*}{ 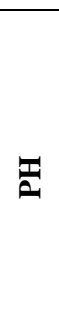 } & \multirow[b]{2}{*}{ 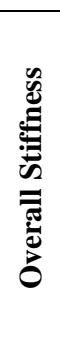 } & \multirow[b]{2}{*}{ 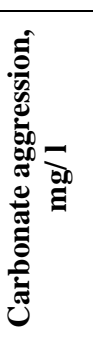 } & \multirow[b]{2}{*}{ 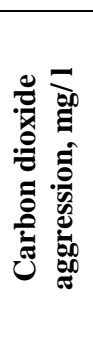 } & \multirow[b]{2}{*}{ 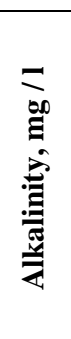 } & \multirow[b]{2}{*}{ 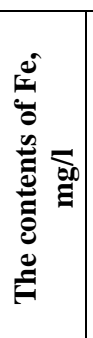 } & \multirow[b]{2}{*}{ 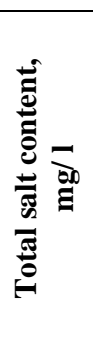 } & \multirow[b]{2}{*}{ 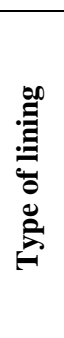 } & \multirow[b]{2}{*}{ 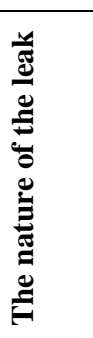 } & \multirow[b]{2}{*}{ 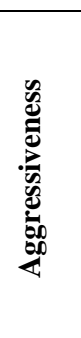 } \\
\hline & 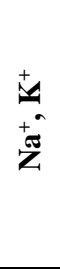 & లే & $\sum_{\sum}^{+\infty}$ & $\dot{0}$ & 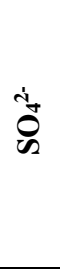 & نै & $\overbrace{0}^{\infty}$ & tั & & & & & & & & & & \\
\hline$\dot{-}$ & $\begin{array}{l}\infty \\
\dot{ల}^{0}\end{array}$ & 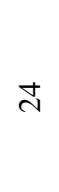 & $\hat{त}^{m}$ & $\mathscr{0}$ & $\underset{\substack{\infty \\
\hdashline}}{\infty}$ & ల & $\Xi$ & ' & $\infty_{\infty}^{\circ}$ & $\stackrel{b}{m}$ & ' & ' & 5 & 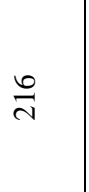 & & $\overline{\tilde{z}}$ & & 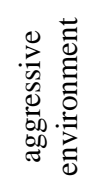 \\
\hline i & $\underline{6}$ & $\stackrel{\infty}{0}$ & $\hat{n}$ & g & $\stackrel{\vec{d}}{\vec{m}}$ & ' & $\hat{\sigma}$ & $\stackrel{\infty}{\mathfrak{I}}$ & ñ & $\begin{array}{l}0 \\
\infty \\
-\infty\end{array}$ & à & ' & $\stackrel{\Xi}{\Xi}$ & $\frac{n}{b}$ & & 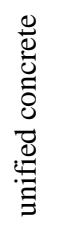 & 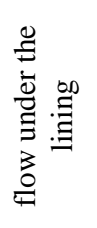 & 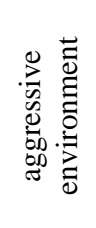 \\
\hline$\dot{r}$ & $\cong$ & $\stackrel{\infty}{\sim}$ & $\begin{array}{l}0 \\
\hat{a}\end{array}$ & 导 & है & ' & $\stackrel{\infty}{\stackrel{\infty}{+}}$ & ' & $\hat{\sigma}$ & $\begin{array}{l}\infty \\
\stackrel{ \pm}{ \pm}\end{array}$ & $\infty$ & $\frac{m}{m}$ & $\infty$ & & 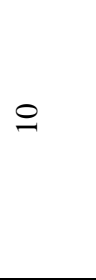 & 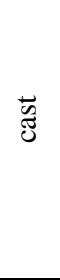 & 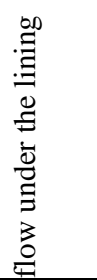 & 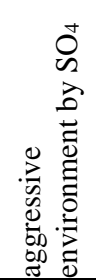 \\
\hline
\end{tabular}




\begin{tabular}{|c|c|c|c|c|c|c|c|c|c|c|c|c|c|c|c|c|c|c|}
\hline$\dot{r}$ & $\stackrel{n}{\stackrel{2}{\Omega}}$ & 过 & $\begin{array}{l}\infty \\
\stackrel{\infty}{+}\end{array}$ & $\stackrel{\infty}{ \pm}$ & $\frac{N}{m}$ & , & $\begin{array}{l}0 \\
\hat{\delta} \\
+\end{array}$ & , & જે & $\stackrel{N}{=}$ & $\stackrel{0}{\sim}$ & $\begin{array}{l}0 \\
\infty \\
\stackrel{0}{0}\end{array}$ & $\stackrel{0}{\sim}$ & , & $\stackrel{+}{\stackrel{5}{\varrho}}$ & $\overrightarrow{\tilde{J}}$ & 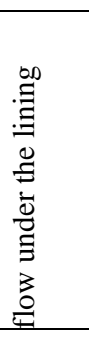 & 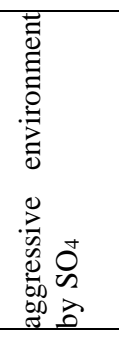 \\
\hline in & å & q & के & $\stackrel{0}{0}$ & $\stackrel{n}{\varrho}$ & ' & $\begin{array}{l}+ \\
\text { do } \\
\text { di }\end{array}$ & ' & 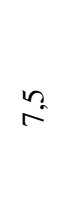 & $\stackrel{\infty}{0}^{\infty}$ & $\stackrel{+}{+}$ & $m_{a}^{2}$ & $\stackrel{+}{+}$ & , & $\stackrel{m}{m}$ & $\overrightarrow{\tilde{g}}$ & 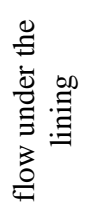 & 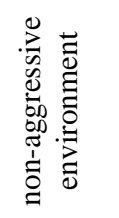 \\
\hline 0 & $\tilde{\sigma}$ & ㄱ. & $\begin{array}{l}0 \\
\dot{0}\end{array}$ & $\simeq$ & $\stackrel{\infty}{+}$ & ' & $\underset{\sim}{\mathbb{~}}$ & ' & $\approx$ & $\nabla$ & $\nabla$ & $\stackrel{+}{\forall}$ & $\nabla$ & ' & 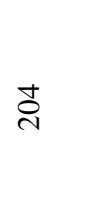 & $\vec{v}$ & 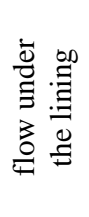 & 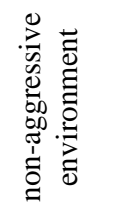 \\
\hline$\dot{r}$ & $a_{\sigma}^{2}$ & ㄱ. & $\begin{array}{l}b^{\circ} \\
\dot{m}^{-1}\end{array}$ & $\simeq$ & $\stackrel{\infty}{+}$ & ' & $\underset{\sim}{\stackrel{Z}{~}}$ & ' & $\stackrel{n}{\sim}$ & ナ & ナ & $\stackrel{+}{\forall}$ & $\nabla$ & ' & ثे & 丞 & 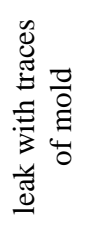 & 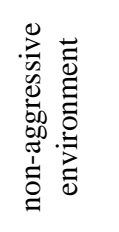 \\
\hline$\infty$ & 岂 & $\stackrel{\triangleright}{\stackrel{\triangleright}{+}}$ & $\underset{\infty}{+}$ & $\triangleright$ & ' & $\stackrel{\text { }}{\Omega}$ & ' & $\frac{n}{n}$ & $\begin{array}{l}0 \\
\infty\end{array}$ & $\begin{array}{l}\infty \\
\stackrel{\infty}{n}\end{array}$ & $\begin{array}{l}\infty \\
\stackrel{n}{n}\end{array}$ & ' & \& & ' & $\underset{0}{0}$ & 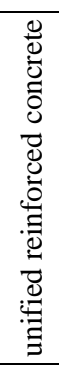 & & 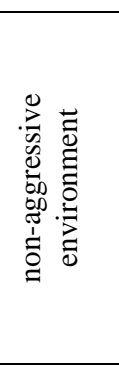 \\
\hline$a^{\circ}$ & $\underset{\sim}{ \pm}$ & 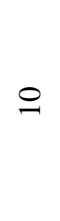 & ' & in & $\frac{n}{6}$ & ' & $\begin{array}{l}n \\
\text { on } \\
\text { nan }\end{array}$ & ' & $\stackrel{n}{\sim}$ & $\tilde{0}$ & $\ddot{n}$ & $\stackrel{0}{0}_{0}^{0}$ & in & ' & $\frac{u}{N}$ & $\overrightarrow{\mathrm{g}}$ & ' & 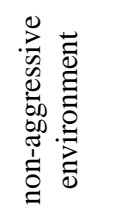 \\
\hline$\stackrel{\circ}{\circ}$ & oे & 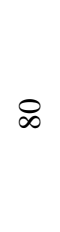 & $\stackrel{\mathfrak{c}}{\mathrm{C}}$ & $\stackrel{\infty}{-}$ & $\hat{\tilde{a}}$ & ' & ' & $\infty$ & $\hat{\infty}$ & 인 & ' & ' & $\nabla$ & ' & $\stackrel{\mathcal{Y}}{\underset{J}{J}}$ & $\overrightarrow{\tilde{J}}$ & 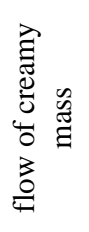 & 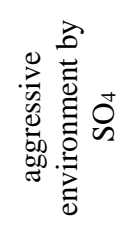 \\
\hline$\dot{\Xi}$ & $\stackrel{\stackrel{Y}{f}}{\stackrel{f}{*}}$ & $\stackrel{\infty}{\sim}$ & $\stackrel{n}{r}$ & g & $\hat{\sigma}$ & ' & $\begin{array}{l}n \\
\text { ñ } \\
\end{array}$ & ' & $\hat{\sigma}$ & 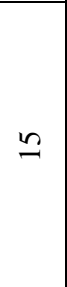 & $\stackrel{n}{i}$ & m & $\vec{n}$ & $\stackrel{n}{\simeq}$ & $\stackrel{m}{\varrho}$ & 芯 & 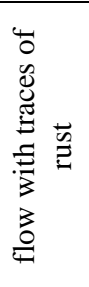 & 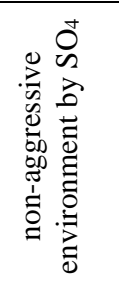 \\
\hline
\end{tabular}




\begin{tabular}{|c|c|c|c|c|c|c|c|c|c|c|c|c|c|c|c|c|c|}
\hline ৯ & $\begin{array}{l}0 \\
\stackrel{\vec{f}}{m}\end{array}$ & $\stackrel{\infty}{\subseteq}$ & $\begin{array}{l}\stackrel{+}{d} \\
\stackrel{2}{2}\end{array}$ & $\infty$ & $\frac{m}{n}$ & & ષુ & ' & 6 & $\underset{\infty}{+}$ & $\stackrel{+}{\infty}$ & $\begin{array}{l}\infty \\
\Uparrow \\
i n\end{array}$ & $\stackrel{+}{\varrho}$ & ఫิ & 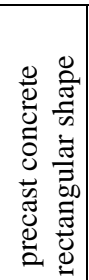 & - & 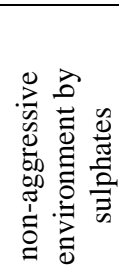 \\
\hline 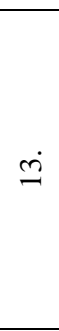 & $\begin{array}{l}\infty \\
\text { si } \\
\text { ge }\end{array}$ & $\stackrel{\infty}{0}$ & ते & 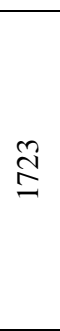 & a & ' & $\frac{7}{n}$ & 1 & r & $\stackrel{n}{n}$ & $\underset{\infty}{+}$ & $\begin{array}{l}\stackrel{0}{ } \\
\simeq\end{array}$ & $\underset{\infty}{+\infty}$ & $\underset{\Xi}{\mathbb{Z}}$ & 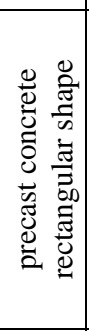 & - & 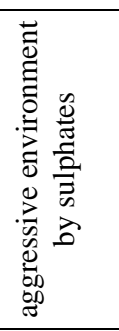 \\
\hline$\dot{ \pm}$ & $\frac{2}{\sigma}$ & q & $\begin{array}{l}\infty \\
\text { o. } \\
o\end{array}$ & in & $\begin{array}{l}0^{0} \\
\text { fo }\end{array}$ & en & 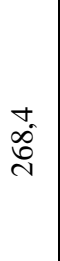 & ' & $\stackrel{n}{\sim}$ & 6 & $\begin{array}{l}0 \\
\text { in }\end{array}$ & ' & $\begin{array}{l}0 \\
\text { in }\end{array}$ & $\stackrel{\ominus}{\gamma}$ & 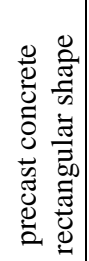 & 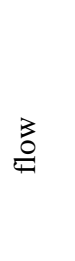 & 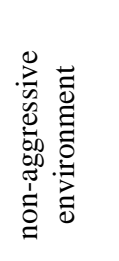 \\
\hline$\ddot{n}$ & $\begin{array}{l}n \\
\tilde{n} \\
0\end{array}$ & $\stackrel{0}{d}$ & $\|$ & $\alpha$ & $\underset{\tilde{\sigma}}{\tilde{b}}$ & $\stackrel{\sim}{\sim}$ & ' & $\begin{array}{l}\stackrel{ \pm}{\Delta} \\
\stackrel{\Delta}{J}\end{array}$ & $\hat{\infty}$ & $\begin{array}{l}\infty \\
\stackrel{I}{I}\end{array}$ & \pm & ' & \pm & ลै & 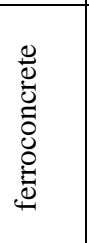 & - & 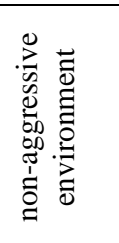 \\
\hline
\end{tabular}

